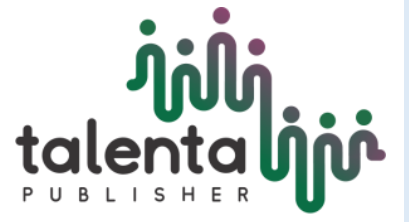

Intepnational doupmal of Ecophysiology

\title{
Synthetic Peptides as Immunogen in the Production of IgY Anti-C-Myc Antibody in Local Chicken (Gallus gallus)
}

\author{
Salomo Hutahaean', Destriani Novita Hasibuan'2, Hanna Omega Tobing', \\ Rohana Simanjuntak, Anissa Willy Halimas ${ }^{2}$, Tombak Antonius \\ Pakpahan $^{2}$
}

${ }^{1}$ Department of Biology FMIPA Universitas Sumatera Utara, Medan, Jl. Biotechnology 1 Padangbulan, Medan; 2 Students at Biology FMIPA Universitas Sumatera Utara, Medan

\begin{abstract}
Experiments conducted to determine the effect of doses of immunogen on the levels of IgY c-Myc antibody in chickens. To generate antibody, we used a synthetic peptide as an immunogen, which is developed from the epitope of the c-Myc protein. Hens were immunized a week after their first eggs were produced. Antigen diluted in double distilled water and emulsified with Freund 's Complete Adjuvant. The suspension was injected into the area of the chicken breast subcutaneously with a dose of $0,0.02$, $0.04,0.06,0.08,0.1,0.12,0.14$, or $0.16 \mathrm{mg}$ per hen. Booster injection performed on days 10, 20, and 30 with the same volume of emulsion, but using Incomplete Freund 's Adjuvant and the amount of antigen was half of the amount of the first Immunization. Extraction of IgY from eggs was carried out using kits from Gallus Immunotech. The level of IgY was quantified using a spectrophotometer where the absorbance was read at $280 \mathrm{~nm}$. The results showed that after the first immunization IgY content of the egg were reached the level of $>5 \mathrm{mg} / \mathrm{ml}$ yolk when the dose of immunogen was above $0.1 \mathrm{mg} / \mathrm{hen}$. The level was higher in eggs produced after the third booster ( $>8 \mathrm{mg} / \mathrm{ml}$ yolk), but it is lower in all groups treated with immunogen above $0.1 \mathrm{mg} / \mathrm{hen}$. We concluded, immunogen dosage of $0.1 \mathrm{mg} / \mathrm{hen}$ was optimum in the production of chicken IgY anti-cMyc.
\end{abstract}

Keywords: IgY antibody, synthetic peptide, chicken anti-c-Myc

Received 1 July 2019 | Revised 20 August 2019| Accepted 31 August 2019

\section{Introduction}

The currently marketed antibodies are generally produced in the bodies of mammals. The process gives a relatively small amount of products because antibodies must be extracted from

\footnotetext{
*Corresponding author at: University of Jambi, Jl. Jambi Ma-Bulian, Postal Code 36361 Indonesia

E-mail address: salomo@usu.ac.id
} 
the blood of test animals which are generally only possible to be taken in limited volumes. In addition, the production of antibody production in the mammal body has not been able to prevent test animals from stress and pain, both stress and pain caused by immunogen and adjuvant injections, as well as suffering caused by repeated blood sampling for antibody extraction. Some researchers have demonstrated the production of antibodies in poultry ( $\operatorname{IgY}$ ) as an alternative to antibody production in mammal animals (Polson, 1990; Gassmann et al, 1990; Hanly et al., 1995). IgY products for almost all purposes are equivalent to mammalian IgG.

Phylogenetically, poultry is far from mammals, therefore, the antibodies produced are superior, especially if the antibodies are used for the detection of mammalian proteins because the amino acid sequence of intracellular proteins among many mammalian species tends to be conserved. In addition, IgY is extracted from egg yolks, thus eliminating the need for blood collection and producing greater quantities of antibodies from laboratory mice.

The c-Myc protein is a transcription factor encoded by the c-Myc gene. The c-Myc protein plays an important role in normal cell growth and proliferation, and in the development of tumor cells, so that the c-Myc gene and its protein products become one of the most widely studied proteins to get a better understanding of embryonic development and cell development cancer (Chen He, et al., 2008). Immunodetection techniques in studying gene expression at the protein level generally require specific antibodies developed against the protein being studied.

The immunogenicity or ability of a molecule to induce a humoral response is determined by its immunogenic properties such as foreignness, molecular weight, chemical composition, and molecular complexity. In addition, the development of an immune response still depends on other factors, such as animal genotypes (for MHC molecules, T cell receptors and B receptors), adjuvants, immunization routes, and immunogen doses given. Too low a dose will fail to activate the lymphocyte response, while too high a dose can flood the system and cause lymphocytes to enter a non-responsive state.

\section{Materials and Methods}

\subsection{Immunogen Preparation}

Immunogen molecules used are synthetic peptides prepared from the results of the prediction of c-Myc protein epitope (Hutahaean, 2012; 2015). Epitope c-Myc is predicted from the amino acid sequence c-Myc derived from human mRNA. Sequences are obtained from the NCBI database (RefSeq / protein_id = NP_002458.2). The c-Myc epitope prediction is done online on the ProPred-1 server (http://www.imtech.res.in/raghava/propred1/). The amino acid c-Myc sequence data in FASTA format is copied and pasted into the system. Predictive results in the form of several candidate epitope sequences are then manually filtered to get one segment that has high immunogenicity. 
Epitope candidates follow the following conditions whenever possible: a). does not contain Proline, Cystein, and Methionine. b). Amino acids are exposed (e), not immersed (b). c.) not a helical region. d). does not contain N-terminal Aspergine. e). does not contain Aspartic acid which combines with Glycine, Proline, and serine. f). there are no multiple Serine and Proline. g). there are no serial sequences of Glutamine, Isoleusine, Leusine, Phenylalanine, Threonin, Tyrosine, or Valin (Angeletti, 1999). From manual screening, a short segment of the peptide consisting of 10 amino acids (EQKLISEEDL) was determined to be prepared as an immunogen. Peptide molecules are then synthesized based on epitope sequences with the addition of cysteine to C-terminal and Keyhole Limpet Hemocyanin (KLH) as a carrier protein. Peptide synthesis is made in a way paid to the company GenScript, USA.

\subsection{Immunization Protocol}

Female native chickens were immunized with synthetic peptides on the third day after entering the laying period. C-Myc synthetic peptide with varying doses $(0,0.02,0.04,0.06$, $0.08,0.1,0.12,0.14$, or $0.16 \mathrm{mg}$ ) dissolved in double distilled water to the end volume of 750 ml, then emulsified at the same volume as Freund Complete Adjuvant (Pacific Immunology, A \#. 5003).

Mixing synthetic peptides with adjuvants using 2 syringes connected to a 2-way stopcock, with the aim that the mixing takes place with pressure. Immunogens that have been mixed with adjuvants are injected into the subcutaneous space (subcutaneous) in the chest area. Booster immunization is carried out on days 10,20 , and 30 with the same emulsion volume, but using Freund Incomplete Adjuvant and the amount of antigen half of the amount given at the first immunization.

\subsection{IgY Antibody Extraction}

Antibodies are extracted from egg yolks using EggsPress IgY Extraction Kit (Gallus Immunotech Inc.). IgY levels were measured in eggs produced before booster (day 3 and 4 after first immunization) and after the third booster (day 33 and 34 after first immunization). Extraction procedures follow company instructions (Gallus Immunotech Inc.). In summary, egg yolk (yolk) is separated from egg white using an egg separator, then egg yolk is rinsed with distilled water. As much as $1 \mathrm{ml}$ of yolk was transferred into a glass beaker and into it was added 5 volumes of the delipidation reagent (reagent A) $(4 \mathrm{C})$ very slowly while stirring with a low rotary stirrer until evenly mixed. After that, the mixture was left overnight at $4 \mathrm{C}$. The mixture is then centrifuged at $4,000 \mathrm{Xg}$ for 20 minutes at $4 \mathrm{C}$. The supernatant was collected into a beaker glass and added with the same volume extracting reagent (reagent B) while slowly stirring with the stirrer for 5 minutes. Furthermore, the suspension was centrifuged again at 
$4,000 \mathrm{X} \mathrm{g}$ for 20 minutes at $4 \mathrm{C}$. After that, the supernatant was removed and the obtained sediment (IgY) was dissolved by adding $1 \mathrm{ml}$ of PBS.

Product quantification is carried out with the help of a spectrophotometer. 300 microliters of IgY antibody were diluted with 5700 microliters of PBS. The solution is divided into two cuvets, then the absorbance is both read each at a wavelength of $280 \mathrm{~nm}$. The average results are included in the formula to determine IgY concentration (= average absorbance X 20 / 1.35) in $\mathrm{mg} / \mathrm{ml}$ units. As a blank, PBS solution is used.

\section{Result and Discussion}

\subsection{IgY levels of eggs produced before booster immunization}

Immunogen dose affects IgY levels in eggs produced on the third and fourth days after the first immunization $(\mathrm{P}<0.05)$. At that time, booster immunization has not been given. The average difference test showed that the treatment that gave a different effect with the control was the treatment dose above $0.12 \mathrm{mg} / \mathrm{chicken}$. The lower dose produces IgY below $4 \mathrm{mg} / \mathrm{ml}$ of yolk which is not statistically different from the control. Control group eggs contain IgY at low levels ( $<2 \mathrm{mg} / \mathrm{ml}$ yolk) whose presence is not related to treatment antigens. The presence of $\operatorname{IgY}$ obtained in control eggs is caused by test animals naturally exposed to various antigens that the body responds to by the formation of antibodies. As long as the test animals are hygienically maintained, the IgY level in the control group will remain low.

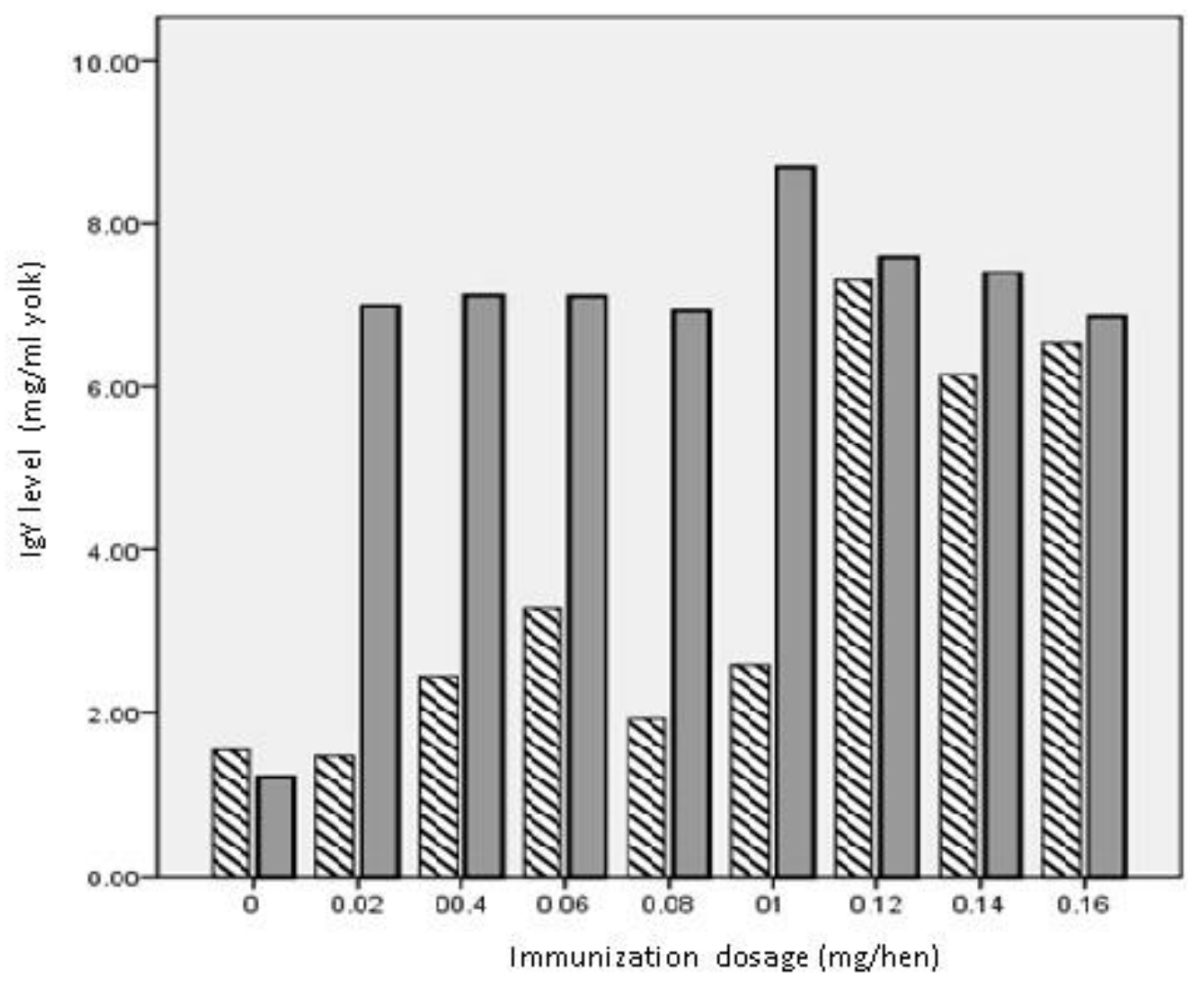


Figure 1. Effect of immunogen doses on levels of $\operatorname{IgY}$ anti-c-Myc native chicken (Gallus gallus). IgY levels were measured in two periods: before boosting immunization and after strengthening (3rd) immunization was given. The optimum effect was achieved at a dose of 0.1 $\mathrm{mg} /$ chicken. Dosages higher than $0.1 \mathrm{mg} /$ chicken tend to have an effect on reducing $\operatorname{IgY}$ levels. Striped bar: before booster; shaded bar: after booster.

In treatment with immunogen doses above $0.1 \mathrm{mg} /$ chicken, $\mathrm{IgY}$ levels obtained were quite high (> $6 \mathrm{mg} / \mathrm{ml}$ yolk). However, it cannot be concluded that in the production of $\operatorname{IgY}$ immunization is sufficiently done once. In observations with a longer period of time and reported separately (Hutahaean et al., 2013), IgY levels examined a few days after the first immunization tended to decrease, and booster immunization was given several times to show a higher level of IgY results.

\subsection{IgY levels of eggs produced after the third booster immunization}

As in eggs examined before booster immunization, IgY levels examined on eggs 33 and 34 days after the first immunization (after third booster immunization) were also significantly influenced by immunogen doses $(\mathrm{P}<0.05)$. After the third booster was given, the smallest dose of immunogen treatment also gave high IgY results, which is above $6 \mathrm{mg} / \mathrm{ml}$ yolk. The highest yield was obtained at a treatment dose of $0.1 \mathrm{mg} /$ chicken, reaching $>8 \mathrm{mg} / \mathrm{ml}$ yolk. Immunogen administration with a dose higher than $0.1 \mathrm{mg} /$ chicken tended to have an effect on reducing $\operatorname{Ig} Y$ levels. It seems that at this dose level immunogen peptide molecules have flooded the immune system of test animals characterized by decreased lymphocyte responsiveness in producing antibodies. It was concluded that for the production of IgY chicken anti-c-Myc polyclonal antibodies in chickens, the best dose of synthetic peptide EQKLISEEDL for the first immunization was $0.1 \mathrm{mg}$ peptide per chicken dissolved in double distilled water to a final volume of $750 \mathrm{ml}$, and emulsified by volume the same is Freund Complete Adjuvant. The dose can produce IgY chicken anti-c-Myc antibodies $>8 \mathrm{mg} / \mathrm{ml}$ yolk, equivalent to about $80 \mathrm{mg}$ of antibodies per egg.

\section{Acknowledgment}

Thank you to the Directorate General of Higher Education of Indonesia for funding this research through the Fundamental Research scheme, 2012 fiscal year.

\section{REFERENCES}

[1] Angeletti, RH. 1999. Design of Useful Peptide Antigens. J Biomol Tech. No.10: 2-10.

[2] Chen He, Huiqing Hu, Rickmer Braren, Shun-Yin Fong, Andreas Trumpp, Timothy R Carlson, RongA Wang. 2008. c-myc in the hematopoietic lineage is crucial for its angiogenic function in the mouse embryo. Development 135: 2467 - 2477. 
[3] Gassmann M, P Thommes, T Weiser, U Hubscher. 1990. Efficient production of chicken egg yolk antibodies against a conserved mammalian protein . The FASEB Journal Vol. 4: 2528-2532.

[4] Hanly, W Canrey, James E Artwohl, B Taylor Bennett . 1995. Review of Polyclonal Antibody Production Procedures in Mammals and Poultry. ILAR Journal V37(3) 1995.

[5] Hutahaean S. 2012. Prediksi Epitop Dan Disain Imunogen Untuk Produksi Antibodi Poliklonal Igy Chicken Anti- C-Myc. Prosiding Seminar Nasional Biologi, Departemen Biologi FMIPA USU Medan, 11 Mei 2012.

[6] Hutahaean, S., I. Aulia., D.N. Hasibuan., E. Prasetyawan., R.E. Limbong. 2013. Preparasi Imunogen untuk Produksi Antibodi IgY anti-c-Myc. Prosiding Hasil-Hasil Penelitian, USU Press, 2013.

[7] Hutahaean, Salomo. Production of Antibody IgY Anti-c-Myc in Chicken Eggs. KnE Life Sciences, p. 330-335, sep. 2015. ISSN 2413-0877. Available at: <https://knepublishing.com/index.php/Kne-Life/article/view/168/1363>. Date accessed: 20 sep. 2018. doi:https://doi.org/10.18502/kls.v2i1.168.

[8] Polson A. 1990. Isolation of IgY from the yolks of eggs by a chloroform polyethylene glycol procedure. Immunol Invest 19: 253-258.

[9] Singh, H., GVS Raghava. 2001. ProPred: Prediction of HLA-DR binding site. Bioinformatics. Application Notes. Vol. 17 No. 12: 1236-1237. 